\title{
Acetobacter oeni sp. nov., isolated from spoiled red wine
}

\author{
Luis R. Silva, ${ }^{1,2}$ Ilse Cleenwerck, ${ }^{3}$ Raúl Rivas, ${ }^{1}$ Jean Swings, ${ }^{3,4}$ \\ Martha E. Trujillo, ${ }^{1}$ Anne Willems ${ }^{4}$ and Encarna Velázquez ${ }^{1}$
}

Correspondence

Encarna Velázquez evp@gugu.usal.es

\author{
${ }^{1}$ Departamento de Microbiología y Génetica, Universidad de Salamanca, Lab. 209, Edificio \\ Departamental de Biología, Campus M. Unamuno, 37007 Salamanca, Spain \\ ${ }^{2}$ Departamento das Industrias Agro-Alimentares, Escola Superior Agrária de Viseu, Portugal \\ ${ }^{3,4}$ BCCM/LMG Bacteria Collection ${ }^{3}$ and Faculty of Sciences ${ }^{4}$, Laboratory of Microbiology, \\ Ghent University, Belgium
}

\begin{abstract}
A bacterial strain, designated $B 13^{\top}$, was isolated from spoiled red wine from the Dão region, Portugal. The strain was Gram-negative, strictly aerobic, rod-shaped and motile. Phylogenetic analysis on the basis of $16 \mathrm{~S}$ rRNA gene sequences indicated that $\mathrm{B}_{1} 3^{\top}$ belonged to the genus Acetobacter within the Alphaproteobacteria. The closest related species was Acetobacter aceti, with $98.4 \% 16 \mathrm{~S}$ rRNA gene sequence similarity. DNA-DNA hybridization showed that B13 ${ }^{\top}$ constituted a taxon separate from the Acetobacter species with validly published names. The DNA $\mathrm{G}+\mathrm{C}$ content of $\mathrm{B} 13^{\top}$ was $58 \cdot 1$ mol\%. Phenotypic characteristics of $\mathrm{B}^{\mathrm{T}} 3^{\top}$ allowed its differentiation from the recognized Acetobacter species. $B 13^{\top}$ produced 5 -ketogluconic acid from glucose, but no 2-ketogluconic acid. It produced catalase, but no oxidase. It utilized glycerol, but not maltose, ethanol or methanol as carbon sources. On the basis of the results obtained, B13 ${ }^{\top}$ represents a novel species for which the name Acetobacter oeni sp. nov. is proposed. The type strain is $B 13^{\top}\left(=\right.$ LMG $21952^{\top}=$ CECT $\left.5830^{\top}\right)$.
\end{abstract}

The genus Acetobacter currently comprises 23 species with validly published names, nine of which have been subsequently transferred to other genera. The Acetobacter species were delineated mainly on the basis of DNA-DNA relatedness and phylogenetic relationships (Sokollek et al., 1998; Lisdiyanti et al., 2000, 2001; Cleenwerck et al., 2002).

During a study of red wine from the Dão region, Portugal, that had been spoiled due to the presence of volatile phenols produced by Dekkera bruxellensis (Silva et al., 2004), a bacterial strain, $\mathrm{B} 13^{\mathrm{T}}$, was recovered. The strain was isolated by spreading $1 \mathrm{ml}$ spoiled red wine samples aseptically on YEDC plates $\left(1^{-1}: 7\right.$ g glucose, 3 g yeast extract, 20 g calcium carbonate and $17 \mathrm{~g}$ agar) where it grew well and produced large haloes due to the solubilization of calcium carbonate by the large amounts of acid secreted by the strain. On this agar, colonies of the novel isolate were mucoid and opaque cream.

Strain $\mathrm{B} 13^{\mathrm{T}}$ was grown on nutrient agar for $48 \mathrm{~h}$ at $22^{\circ} \mathrm{C}$ to check for motility by phase-contrast microscopy. Gram staining of cells was carried out according to the classical

Published online ahead of print on 26 August 2005 as DOI 10.1099/ ijs.0.64000-0.

The GenBank/EMBL/DDBJ accession number for the 16S rRNA gene sequence of Acetobacter oeni sp. nov. B13 ${ }^{\top}$ is AY829472.
Gram procedure described by Doetsch (1981). Strain B13 ${ }^{\mathrm{T}}$ was a Gram-negative, rod-shaped and motile organism with peritrichous flagella $(0 \cdot 8-0 \cdot 9 \times 3 \cdot 6-5 \cdot 1 \mu \mathrm{m})$.

DNA for 16S rRNA gene sequencing was extracted as described by Rivas et al. (2001). Amplification and sequencing of the nearly complete $16 \mathrm{~S}$ rRNA gene were performed as described previously (Rivas et al., 2003). The sequence determined was compared with sequences from GenBank using the BLAST program (Altschul et al., 1990). Phylogenetic analysis was performed using the BIONUMERICS 4.0 software package (Applied Maths). The sequence determined was aligned with similar sequences retrieved from the EMBL database. Nucleotide substitution rates were calculated using the two-parameter method of Kimura (1980). The phylogenetic tree was inferred using the neighbour-joining method (Saitou \& Nei, 1987). Bootstrap analysis based on 1000 replications was undertaken to test the robustness of the phylogenetic tree (Felsenstein, 1985).

The nearly complete $16 \mathrm{~S}$ rRNA gene sequence of $\mathrm{B} 13^{\mathrm{T}}$ (1484 nucleotides) was obtained. $\mathrm{B} 13^{\mathrm{T}}$ was located in the Alphaproteobacteria, within the genus Acetobacter. The sequence similarities of $\mathrm{B}^{\mathrm{T}}{ }^{\mathrm{T}}$ to the type strains of Acetobacter aceti, Acetobacter tropicalis, Acetobacter estunensis, Acetobacter cerevisiae, Acetobacter indonesiensis, Acetobacter 
malorum, Acetobacter orleanensis, Acetobacter orientalis, Acetobacter cibinongensis, Acetobacter syzygii, Acetobacter lovaniensis, Acetobacter pomorum, Acetobacter pasteurianus and Acetobacter peroxydans were 98.3, 98 $1,98 \cdot 0,97 \cdot 9,97 \cdot 9$, $97 \cdot 8,97 \cdot 6,97 \cdot 6,97 \cdot 5,97 \cdot 4,97 \cdot 1,97 \cdot 0,96 \cdot 7$ and $96 \cdot 4 \%$ respectively. Fig. 1 shows the phylogenetic position of strain $\mathrm{B} 13^{\mathrm{T}}$ within the genus Acetobacter.

DNA for DNA-DNA hybridizations and DNA base composition analysis was prepared by the method of Wilson (1987) with minor modifications (Cleenwerck et al., 2002). DNA-DNA hybridizations were performed using a modification of the microplate method described by Ezaki et al. (1989) (Goris et al., 1998; Cleenwerck et al., 2002). The hybridization temperature was $46^{\circ} \mathrm{C}$. Reciprocal reactions (e.g. $\mathrm{A} \times \mathrm{B}$ and $\mathrm{B} \times \mathrm{A}$ ) were performed and the variation between them was within the limits of this method (Goris et al., 1998). The DNA-DNA relatedness percentages presented are the means of a minimum of four hybridization experiments, including the reciprocal reactions. Strain $\mathrm{B} 13^{\mathrm{T}}$ showed low DNA-DNA relatedness ( $\leqslant 20 \%)$ with the type strains of $A$. aceti (13\%), A. tropicalis (14\%), A. estunensis (20\%), A. cerevisiae (13\%), A. indonesiensis (7\%), A. malorum (5\%), A. orleanensis (6\%), A. orientalis (6\%), A. cibinongensis (7\%), A. syzygii (10\%), A. lovaniensis (15\%), A. pomorum $(12 \%), A$. pasteurianus $(16 \%)$ and $A$. peroxydans ( $13 \%)$. The DNA G $+\mathrm{C}$ content was determined by HPLC according to the method of Mesbah et al. (1989). Non-methylated phage lambda DNA (Sigma) was used as the calibration reference. The DNA G $+\mathrm{C}$ content of $\mathrm{B} 13^{\mathrm{T}}$ was $58 \cdot 1 \mathrm{~mol} \%$.
Phenotypic characteristics were examined as described by Cleenwerck et al. (2002). The phenotypic characteristics of $\mathrm{B} 13^{\mathrm{T}}$ are given in the species description. Phenotypic characteristics that differentiate $\mathrm{B} 13^{\mathrm{T}}$ from recognized Acetobacter species are given in Table 1. Strain $\mathrm{B} 13^{\mathrm{T}}$ can be differentiated from the other species of the genus Acetobacter on the basis of 2- and/or 5-ketogluconic acid production from $\mathrm{D}$-glucose, which are the main diagnostic characters for this genus. The ability of the strain to grow in the presence of $10 \%$ ethanol also distinguishes strain $\mathrm{B} 13^{\mathrm{T}}$ from most Acetobacter species. Moreover, strain $\mathrm{B} 13^{\mathrm{T}}$ differs from the closest phylogenetically related species, $A$. aceti and A. estunensis, as it is unable to grow with ammonium as the sole nitrogen source with ethanol as the carbon source.

The results presented above allow the genotypic and phenotypic differentiation of $\mathrm{B}^{\mathrm{T}} 3^{\mathrm{T}}$ from the 14 Acetobacter species with validly published names. Strain $B 13^{\mathrm{T}}$ should therefore be classified as representing a novel species for which we propose the name Acetobacter oeni sp. nov.

\section{Description of Acetobacter oeni sp. nov.}

Acetobacter oeni (oe'ni. N.L. gen. n. oeni of wine from Gr. gen. n. oinou of wine).

Cells are motile, non-spore-forming rods, $3 \cdot 6-5 \cdot 1 \mu \mathrm{m}$ in length and $0 \cdot 8-0.9 \mu \mathrm{m}$ in diameter. Gram-negative, strictly aerobic. The optimal growth temperature on YEDC is $28^{\circ} \mathrm{C}$. Colonies on YEDC are circular, convex, cream, opaque and usually 1-2 $\mathrm{mm}$ in diameter within 4 days growth at $28^{\circ} \mathrm{C}$.

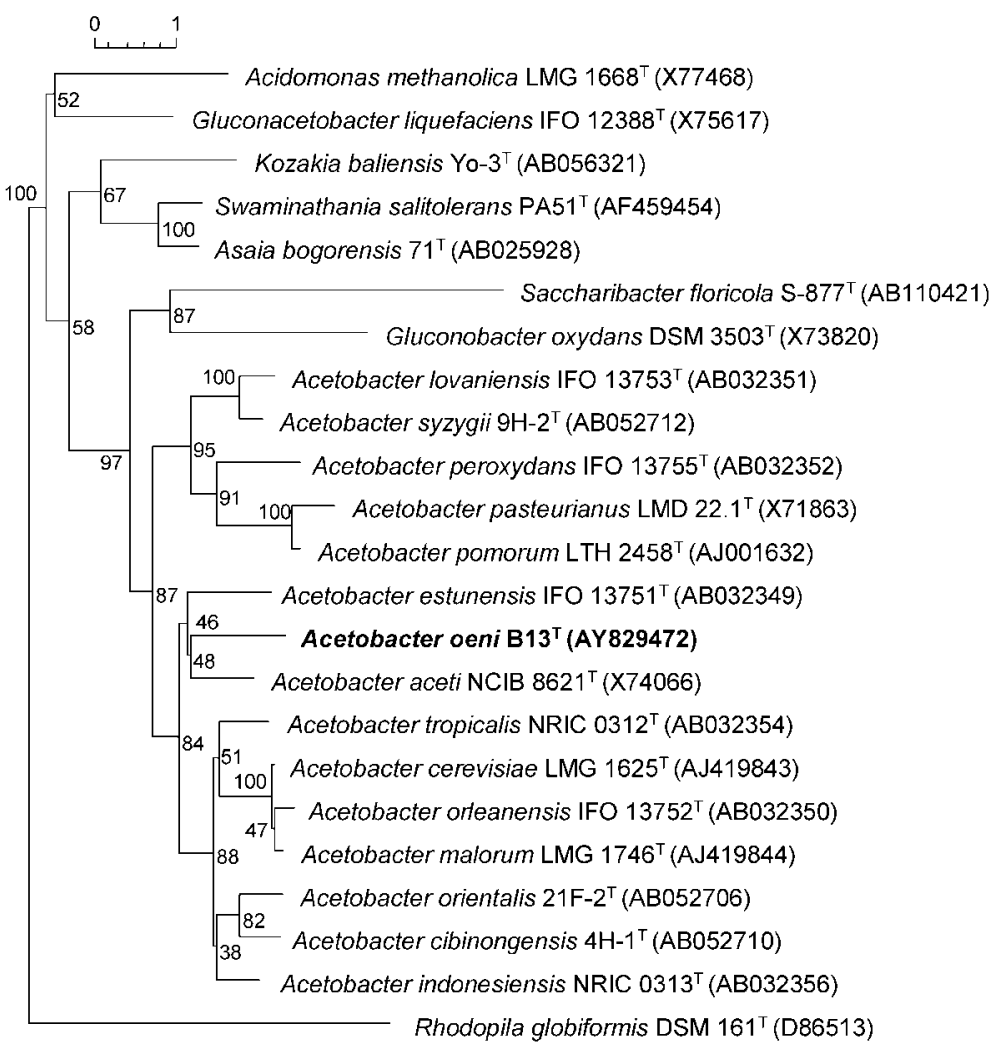

Fig. 1. Neighbour-joining tree based on nearly complete $16 \mathrm{~S}$ rRNA gene sequences of Acetobacter oeni $\mathrm{B}_{1} 3^{\top}$ and other related species of the family Acetobacteraceae. The significance of each branch is indicated by a bootstrap value (\%) calculated for 1000 subsets. Bar, 1 substitution per 100 nucleotides. 


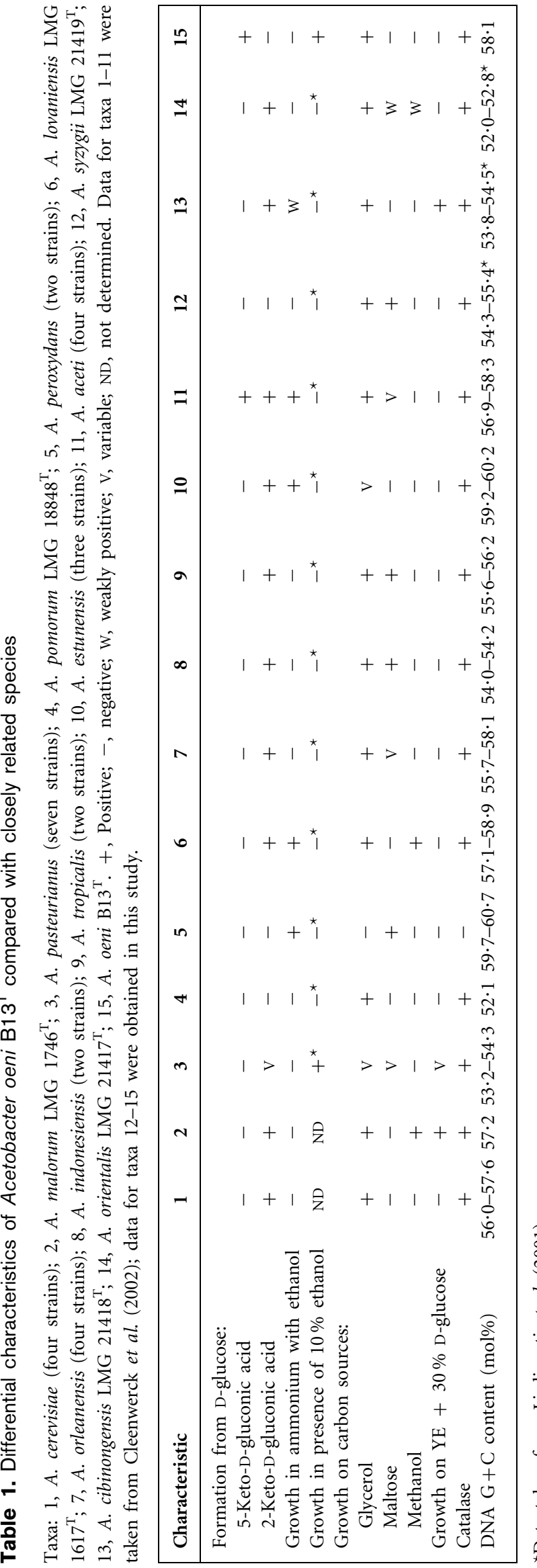

Produces 5-keto-D-gluconic acid from D-glucose but no 2-keto-D-gluconic acid. Oxidizes D-glucose in media containing ammonium nitrate as the nitrogen source, but is unable to ferment D-glucose in the same media. Produces catalase, but no oxidase. Unable to grow with ammonium as the nitrogen source with ethanol as carbon source. Growth in presence of $10 \%$ ethanol. Utilizes glycerol as a carbon source, but not maltose or methanol. No growth in the presence of $30 \%$ D-glucose. DNA G $+\mathrm{C}$ content of $58 \cdot 1 \mathrm{~mol} \%$.

The type strain, $\mathrm{B} 13^{\mathrm{T}}\left(=\right.$ LMG $21952^{\mathrm{T}}=$ CECT $\left.5830^{\mathrm{T}}\right)$, was isolated from spoiled red wine of the Dão region, Portugal.

\section{Acknowledgements}

This work was supported by CAICYT-DGES and JCyL (Spanish Government). We wish to thank K. Engelbeen for her technical assistance with the DNA-DNA hybridizations and phenotypic tests. A. W. is grateful to the Fund for Scientific Research - Flanders for a postdoctoral fellowship.

\section{References}

Altschul, S. F., Gish, W., Miller, W., Myers, E. W. \& Lipman, D. J. (1990). Basic local alignment search tool. J Mol Biol 215, 403-410.

Cleenwerck, I., Vandemeulebroecke, K., Janssens, D. \& Swings, J. (2002). Re-examination of the genus Acetobacter, with descriptions of Acetobacter cerevisiae sp. nov. and Acetobacter malorum sp. nov. Int J Syst Evol Microbiol 52, 1551-1558.

Doetsch, R. N. (1981). Determinative methods of light microscopy. In Manual of Methods for General Bacteriology, pp. 21-33. Edited by P. Gerdhardt, R. G. E. Murray, R. N. Costilow, E. W. Nester, W. A. Wood, N. R. Krieg \& G. B. Phillips. Washington, DC: American Society for Microbiology.

Ezaki, T., Hashimoto, Y. \& Yabuuchi, E. (1989). Fluorometric deoxyribonucleic acid-deoxyribonucleic acid hybridization in microdilution wells as an alternative to membrane filter hybridization in which radioisotopes are used to determine genetic relatedness among bacterial strains. Int J Syst Bacteriol 39, 224-229.

Felsenstein, J. (1985). Confidence limits on phylogenies: an approach using the bootstrap. Evolution 39, 783-791.

Goris, J., Suzuki, K., De Vos, P., Nakase, T. \& Kersters, K. (1998). Evaluation of a microplate DNA-DNA hybridization method compared with the initial renaturation method. Can J Microbiol 44, 1148-1153.

Kimura, M. (1980). A simple method for estimating evolutionary rates of base substitutions through comparative studies of nucleotide sequences. J Mol Evol 16, 111-120.

Lisdiyanti, P., Kawasaki, H., Seki, T., Yamada, Y., Uchimura, T. \& Komagata, K. (2000). Systematic study of the genus Acetobacter with descriptions of Acetobacter indonesiensis sp. nov., Acetobacter tropicalis sp. nov., Acetobacter orleanensis (Henneberg 1906) comb. nov., Acetobacter lovaniensis (Frateur 1950) comb. nov., and Acetobacter estunensis (Carr 1958) comb. nov. J Gen Appl Microbiol 46, 147-165.

Lisdiyanti, P., Kawasaki, H., Seki, T., Yamada, Y., Uchimura, T. \& Komagata, K. (2001). Identification of Acetobacter strains isolated from Indonesian sources, and proposals of Acetobacter syzygii sp. nov., Acetobacter cibinongensis sp. nov., and Acetobacter orientalis sp. nov. J Gen Appl Microbiol 47, 119-131. 
Mesbah, M., Premachandran, U. \& Whitman, W. B. (1989). Precise measurement of the $\mathrm{G}+\mathrm{C}$ content of deoxyribonucleic acid by high-performance liquid chromatography. Int J Syst Bacteriol 39, 159-167.

Rivas, R., Velázquez, E., Valverde, A., Mateos, P. F. \& MartínezMolina, E. (2001). A two primers random amplified polymorphic DNA procedure to obtain polymerase chain reaction fingerprints of bacterial species. Electrophoresis 22, 1086-1089.

Rivas, R., Willems, A., Subba-Rao, N. S., Mateos, P. F., Kroppenstedt, R., Martínez-Molina, E., Gillis, M. \& Velázquez, E. (2003). Description of Devosia neptuniae sp. nov. that nodulates and fixes nitrogen in symbiosis with Neptunia natans, an aquatic legume from India. Syst Appl Microbiol 26, 47-53.
Saitou, N. \& Nei, M. (1987). The neighbour-joining method: a new method for reconstructing phylogenetic trees. Mol Biol Evol 4, 406-425. Silva, L. R., Andrade, P. B., Valentão, P., Seabra, R. M., Trujillo, M. E. \& Velázquez, E. (2004). Analysis of non-coloured phenolics in red wine: effect of Dekkera bruxellensis yeast. Food Chem 89, 185-189.

Sokollek, S. J., Hertel, C. \& Hammes, W. P. (1998). Description of Acetobacter oboediens sp. nov. and Acetobacter pomorum sp. nov., two new species isolated from industrial vinegar fermentations. Int J Syst Bacteriol 48, 935-940.

Wilson, K. (1987). Preparation of genomic DNA from bacteria. In Current Protocols in Molecular Biology, pp. 2.4.1-2.4.5. Edited by F. M. Ausubel, R. Brent, R. E. Kingston, D. D. Moore, J. G. Seidman, J. A. Smith \& K. Struhl. New York: Green Publishing \& Wiley-Interscience. 